\title{
Galvayne's groove and the presence of a hook on the upper corner incisors are poor indicators of age in horse teeth
}

\author{
Sofie Muylle?, Günther van Loon² and Paul Simoens? \\ Dept. of Morphology ${ }^{1}$ and Dept. of Internal Medicine of Large Animals², Faculty of Veterinary Medicine, Ghent University
}

\begin{abstract}
Summary
Galvayne's groove and the dental hook are two characteristic features of the upper corner incisors of horses. Both characteristics have traditionally been claimed to appear at specific ages and have therefore often been used for dental age determination. Recent studies, however, have questioned the accuracy of these criteria and concluded that the presence of a 7 -year-hook is irrelevant for estimation of age in horses, whereas Galvayne's groove may be a useful adjunct after all other morphological criteria have been considered. The present paper intends to illustrate the variable appearance of both characteristics in the dentition of Standardbred, Arabian and Belgian draft horses and in mini-Shetlandponies $(n=490)$ ranging in age from 5 to 28 years old.
\end{abstract}

Keywords: Horse, age determination, incisor, hook, Galvayne's groove

\begin{abstract}
Galvayne-Rinne und Einbiss am oberen Eckschneidezahn sind schlechte Indikatoren für die Altersbestimmung des Pferdes
Die "Galvayne-Rinne" und der "Einbiss" sind charakteristische Kennzeichen des Eckschneidezahns im Oberkiefer. Für beide Merkmale wurde bisher angenommen, dass sie jeweils in einem bestimmten Alter erstmalig in Erscheinung treten. Deshalb sind sie als Kriterien für die Alterschätzung herangezogen worden. Aktuelle Untersuchungen stellen die Genauigkeit dieser Kriterien allerdings in Frage. Das Erscheinen des ersten Einbisses (engl. "7-year-hook") ist demnach irrelevant für die Altersschätzung eines Pferdes. Die Galvayne-Rinne kann eine Altersschätzung sinnvoll ergänzen, unter der Vorraussetzung dass alle anderen morphologischen Kriterien ausreichend berücksichtigt wurden. Die vorliegende Arbeit veranschaulicht die Variabilität beider Merkmale im Gebiss verschiedener Pferderassen (Traber, Araber, Belgisches Kaltblut, Mini-Shetland-Ponies; $\mathrm{n}=490$; Alter: 5 bis 28 Jahre).
\end{abstract}

Schlüsselwörter: Pferd, Altersbestimmung, Schneidezahn, Einbiss, Galvayne-Rinne

\section{Introduction}

Age determination in horses based on the appearance and morphology of the incisor teeth is a technique that has been mentioned for the first time in 600 BC (Kertesz 1993). It relies on several criteria including the eruption of both the deciduous and permanent teeth, the presence of dental stars and infundibula, changes in shape of the occlusal surfaces and changes in the arch formed by the upper and lower incisors. The dental ageing technique has been questioned and revised several times and has resulted in a copious amount of specialist literature on the subject (Walmsley 1993, Richardson et al. 1994, Dyce et al. 1996, Muylle et al. 1996, 1997, 1998, Barone 1997, AAEP 2002).

Two features that are still frequently mentioned as criteria for age determination in horses are Galvayne's groove and the presence of a hook on the upper corner incisor.

Galvayne's groove is a longitudinal depression on the vestibular surface of the upper permanent corner. In young horses the groove is burried within the bony dental alveole, but with advancing age and due to the continuous eruption of the tooth the distal end of the groove starts appearing at the gumline. In progress of time this distal end proceeds halfway down the crown and then reaches the occlusal rim. With further incisival eruption the proximal end of the groove appears at the gumline, protrudes and finally reaches the occlusal surface, which leads to the disappearance of Galvayne's groove.

The age-related appearance of the groove on the vestibular surface of the upper corner was promoted in 1880 by an American horse tamer who travelled through Australia and styled himself as Professor Sample (Kertesz 1993). Sidney Galvayne plagiarized Sample's ideas and brought them to England where he edited a small book 'Horse Dentition: Showing how to tell exactly the age of a horse up to 30 years', spreading Sample's ideas in the English speaking world (McCarthy 1987).

The dental hook is a localised dental overgrowth that is sometimes present at the caudal third segment of the occlusal surface of the upper corner incisor. This overgrowth develops when the lower occlusal tables undergo a more pronounced rostral movement during incisival protrusion when compared to their upper counterparts. This unequal rostral displacement is caused by a different curvature of the upper and lower incisors, the upper corner showing a more pronounced labially convex arc than the lower corner. When as a result the cau- 

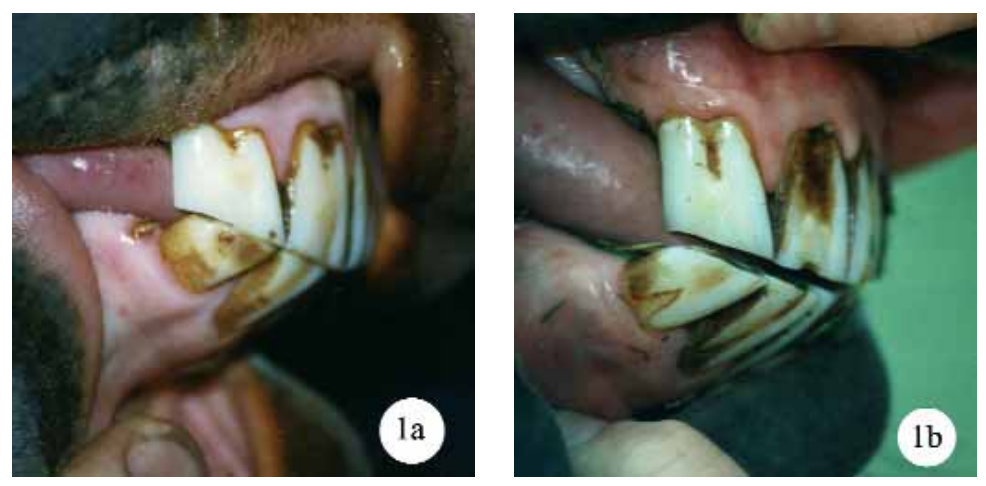

Fig 1 (a-d) Variable length of Galvayne's groove extending for one quarter (a) (Standardbred, 11 years), one half (b) (Standardbred, 11 years), three quarters (c) (Standardbred, 17 years) or all the way down (d) (Standardbred, 17 years) the vestibular surface of the upper corner.

Unterschiedliche Länge der Galvayne-Rinne über ein Viertel (a)(Traber, 11 Jahre), die Hälfte (b)(Traber, 11 Jahre), drei Viertel (c) (Traber 17 Jahre) oder die ganze Länge (d)(Traber, 17 Jahre) der Außenfläche des Oberkiefereckschneidezahns.
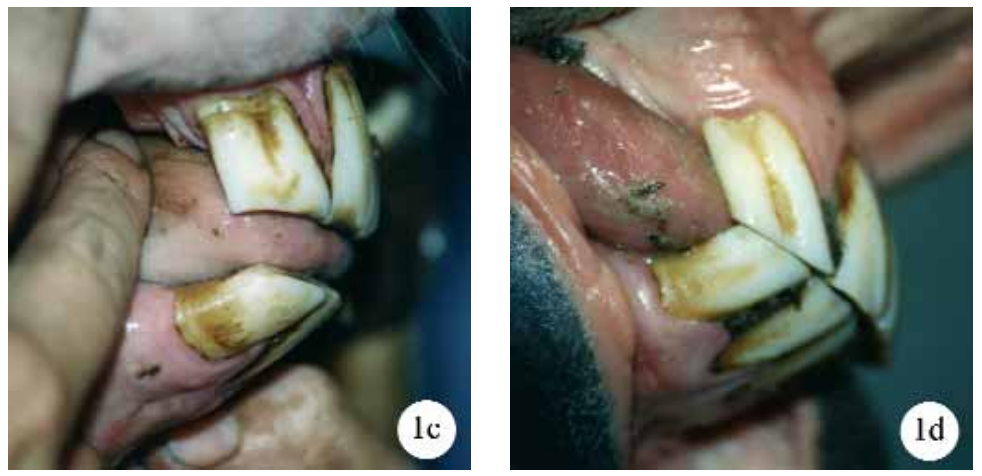

dodistal portion of the upper corner does not contact its lower matching opponent anymore, it wears more slowly and extends as a hook beyond the occlusal surface. This phenomenon has become a well-known and widely used characteristic in dental ageing. Because it was believed for a long time that the hook appeared at the age of 7, it was traditionally called the "7-year-notch" in the English speaking world
(McMullan 1983). In French the hook on the upper corner is identified as échancrure and in German it is referred to as Einbiss.

Although it has often been stated that both features are not absolutely reliable, it was generally accepted that they may enhance dental ageing accuracy when combined with the

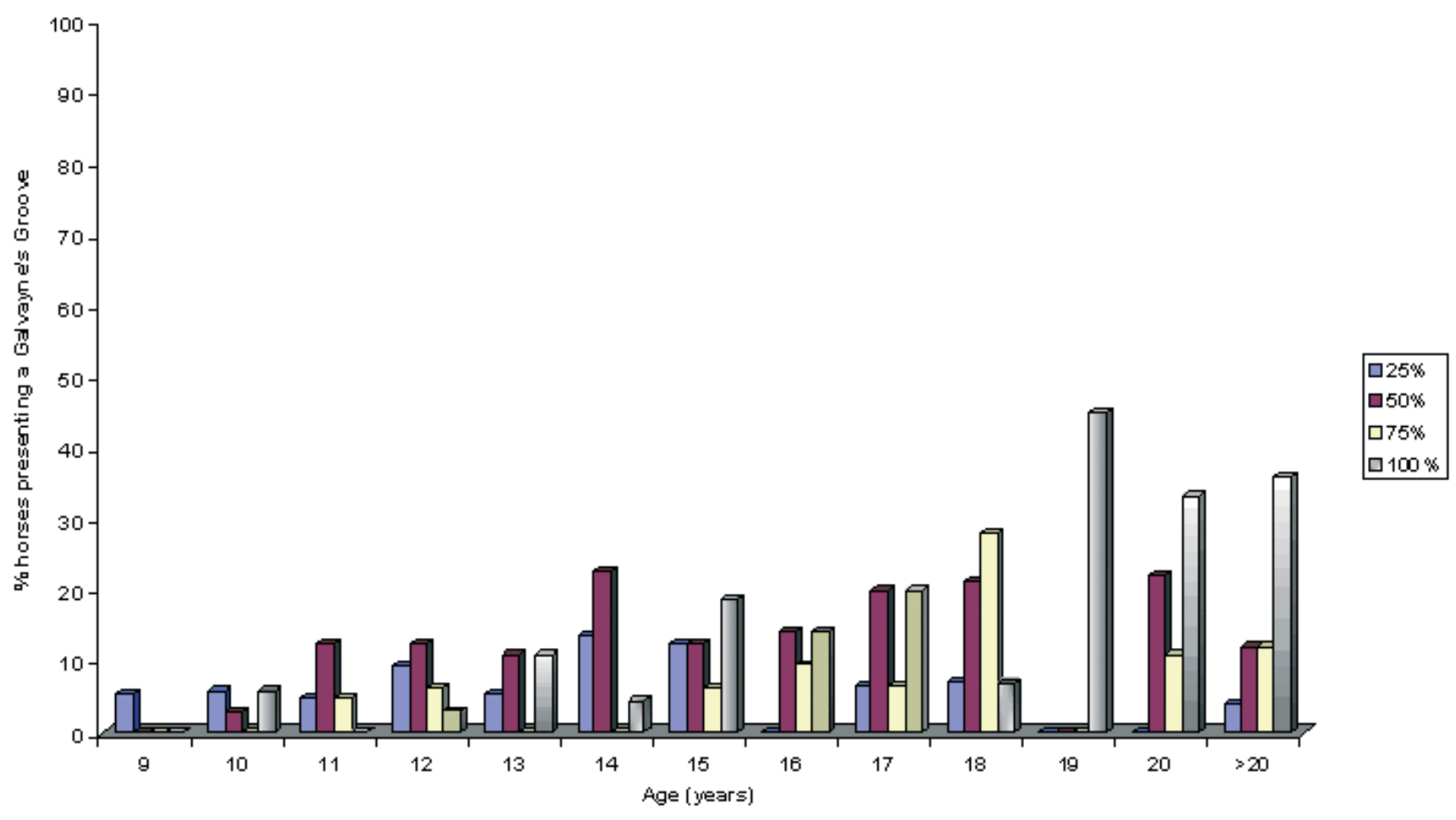

Fig 2 Presence of Galvayne's grooves of different lengths in horses and ponies of 9 years and older $(n=318)$. The variously stained subunits of each age category represent the extent of the grooves (grey $<25 \%$; black 25-50\%; white $50-75 \%$; shaded $>75 \%$ ).

Galvayne-Rinne unterschiedlicher Längen bei Pferden und Ponies von 9 Jahren und älter ( $n=318)$. Die unterschiedlich gefärbten Untergruppen jeder Alterskategorie stehen für die Längen der Rinnen (grau< $<2 \%$, schwarz 25-50\%, weiß 50-75\%, schattiert> 75\%). 
appearance of the occlusal surfaces and the profile of the incisors.

Whereas Galvayne stated that his ageing methods were accurate and unfailable, it is now accepted that dental age determination is far from exact as a multitude of factors can influence the appearance of an individual mouth (Walmsley 1993, Richardson et al. 1994, Dyce et al. 1996, Muylle et al. 1996, 1997, 1998, Barone 1997, AAEP 2002). Factors modifying tooth wear such as breed, nutrition, types of feed stuffs and husbandry make age estimation increasingly unreliable.

The present paper intends to illustrate the variability of both Galvayne's groove and the hook and demonstrates that those characteristics are far from exact or reliable.

\section{Materials and Methods}

The incisor teeth of 490 horses with documented evidence of birth and ranging in age from 5 to 28 years were examined by adspection and photography. The animals belonged to 4 breeds, viz. the Standardbred ( $n=169)$, the Belgian draft horse $(n=126)$, the Arabian horse $(n=132)$ and the miniShetland pony $(n=63)$.

Traditionally, horses are aged in full years, being aged as one year in the calender year following their birth (Walmsley 1993). In the present study however, the animals have been classified according to their exact age (5 years $=5 \pm 0.5$ years).

All 490 animals had a fully permanent dentition and were kept in similar environmental conditions. During the summer they grazed pasture and in winter they were fed concentrates and hay. Horses with anomalies of dental occlusion (inferior/superior brachygnathism) or evidence of untoward wear patterns such as cribbiting were excluded from the study.

The incisival characteristics were examined and after parting the lips for left lateral and right lateral adspection and photography special attention was paid to the presence of a longitudinal groove and a distal angular protrusion on each of both upper corners.

The presence or absence of Galvayne's groove and the hook on both upper corners was recorded. When present the length of Galvayne's groove was classified into four categories: extending for up to one quarter $(25 \%)$, one half $(50 \%)$, three quarters $(75 \%)$ or all the way $(100 \%)$ down the vestibular surface of the upper corner crown (Fig 1 a-d).

\section{Results}

Galvayne's groove was never observed in any horse below nine years of age. The youngest Standardbred horse with Galvayne's groove extending for one quarter of the vestibular dental surface was nine years and five months old. In Belgian draft horses and Arabian horses the youngest individuals presenting a Galvayne's groove were 11 years and six months, and in mini-Shetland ponies the youngest animal with a beginning Galvayne's groove was 13 years and 6 months old.

Galvayne's grooves were observed in all age-categories of horses older than nine years (Standardbred horses), 11 years (Belgian draft horses and Arabian horses) or 13 years (miniShetland ponies). The length of Galvayne's groove varied from a very small notch at the gingival margin in some horses, to a groove extending along the entire vestibular surface. The length of the groove could not be related to specific ages as shown in Figs. 2 and 3. In horses in which Galvayne's groove was present on each of both upper corners, the length of the groove was rarely symmetrical.

In animals of 9 years and older Galvayne's groove was more frequently observed in Standardbreds $(47 / 112$ horses $=$ $42 \%$ ) and Arabian horses (43/114 horses = 38\%) than in draft horses $(6 / 57$ horses $=10.5 \%)$ and Shetland ponies $(6 / 35$ ponies $=17 \%)$.

Hooks were present in 74/456 horses (16\%) ranging from 5 till 19 years old (Figs. 4-5). They were observed in all age categories between 5 and 19 years, but never exceeded $30 \%$ in any of those age categories. In the 34 horses aged 20 years and older hooks were never observed (Fig. 5). When present, the hooks were rarely symmetrical in the left and right incisor.

\section{Discussion}

Galvayne's groove and the hook on the upper corner incisors are two characteristics that are typical for the hypsodont dentition of horses. Both these features are temporarily present on equine teeth and have never been observed in brachydont dentitions. Brachydont or low-crowned teeth, such as the canine and feline dentition and bovine incisors, erupt fully prior to maturity. Because their crowns are completely covered by enamel and not subjected to prolonged and high levels of dietary and abrasive forces, these teeth are hard enough to survive for the life of the animal (Van Foreest 1995, Baker 1999). In contrast, hypsodont or high-crowned equine teeth are subjected for prolonged periods ( 16.5 hours/day) to a diet of large quantities of coarse foodstuffs that contain abrasive silicates (Baker 1999). Equine incisors are specialized for efficient low grazing of grasses but the prehension of this type of foodstuff causes increased occlusal wear. Therefore these teeth have developed a long crown $(75 \mathrm{~mm})$ that is embedded in the alveolar bone and erupts though the gums over most of the horse's life at a rate of 2-3 mm a year (Baker 1985, Dyce et al. 1996).

The high occlusal wear and continuous dental protrusion out of the alveolar bone account for a continuously changing clinical crown and result in the temporary existence of both a hook and a Galvayne's groove.

Galvayne's groove is never observed in young horses because it is absent in the distal half of the vestibular surface of the unworn tooth. It is only when this part of the upper corner has been worn off and the tooth has protruded further through the gums that the groove may become visible on the dental crown. 

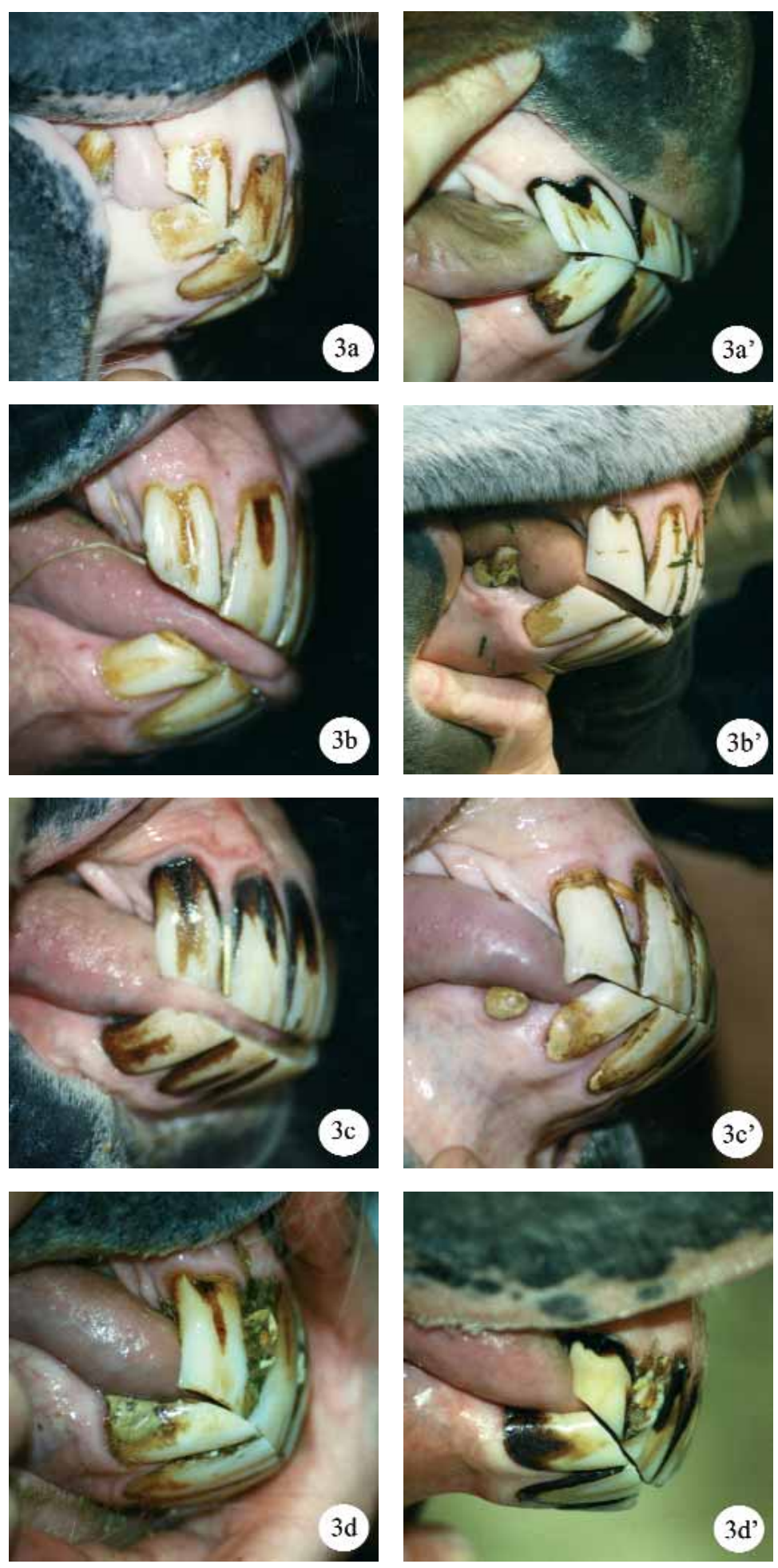

Fig 3 Paired images of horses of the same age showing a different expression of Galvayne's groove. 3a-a': Groove extending for $100 \%$ (a) or nearly $50 \%\left(a^{\prime}\right)$ in 13 year old Arabian horses. 3b-b': Groove extending for nearly 100\% (b) or less than 25\% (b') in 15 year old Arabian horses. 3c-c': Groove extending for nearly $100 \%$ (c) or absent $\left(c^{\prime}\right)$ in 19 year old Arabian horses. 3d-d': Groove extending for $50 \%$ (d) or absent ( $d^{\prime}$ ) in Arabian horses aged over 25 years. Bildpaare von Pferden gleichen Alters mit unterschiedlicher Länge der Galvayne-Rinne. 3a-a': Rinne über eine Länge von 100\% (a) oder annähernd 50\% ( $\left.a^{\prime}\right)$ bei 13 Jahre alten Arabern. 3b-b': Rinne über nahe 100\% (b) oder weniger als 25\% $\left(b^{\prime}\right)$ bei 15 Jahre alten Arabern. 3c-c': Rinne über annähernd $100 \%$ (c) oder nicht vorhandene Rinne (c') bei 19 Jahre alten Arabern. 3d-d': Rinne über eine Länge von 50\% (d) oder nicht vorhanden ( $d^{\prime}$ ) bei Arabern über 25 Jahre alt.
The depth of Galvayne's groove varies among individuals. According to the depth of the longitudinal depression cementum may or may not remain in all or part of the groove. This cementum may or may not have a dark stain (AAEP 2002). Both the abundance and the stain of cementum in Galvayne's groove are responsible for the visibility and appearance of the groove.

When Galvayne's groove is visible, one knows that the upper corner has already protruded through the gums for several years. The groove is therefore characteristic for middle-aged or old horses, but because of its inconstancy absence of this groove does not necessarily prove that the horse is young (<9 years).

Similarly, the appearance of a hook on the upper corner cannot be related to specific age-categories (Fig. 4).

The presence, time of appearance, and size of the hook depend on the curve of the incisors, on the difference in cur- 
Fig 4 Hooks on the upper corner were observed in horses of all ages between 5 and 19 years (SB: Standardbred; BD Belgian Draft horse; $\mathrm{AH}$ : Arabian horse). Einbisse am Oberkiefereckschneidezahn wurden bei Pferden jeden Alters zwischen 5 und 19 Jahren gesehen (SB: Traber, BD: Belgisches Kaltblut, AH: Araber).
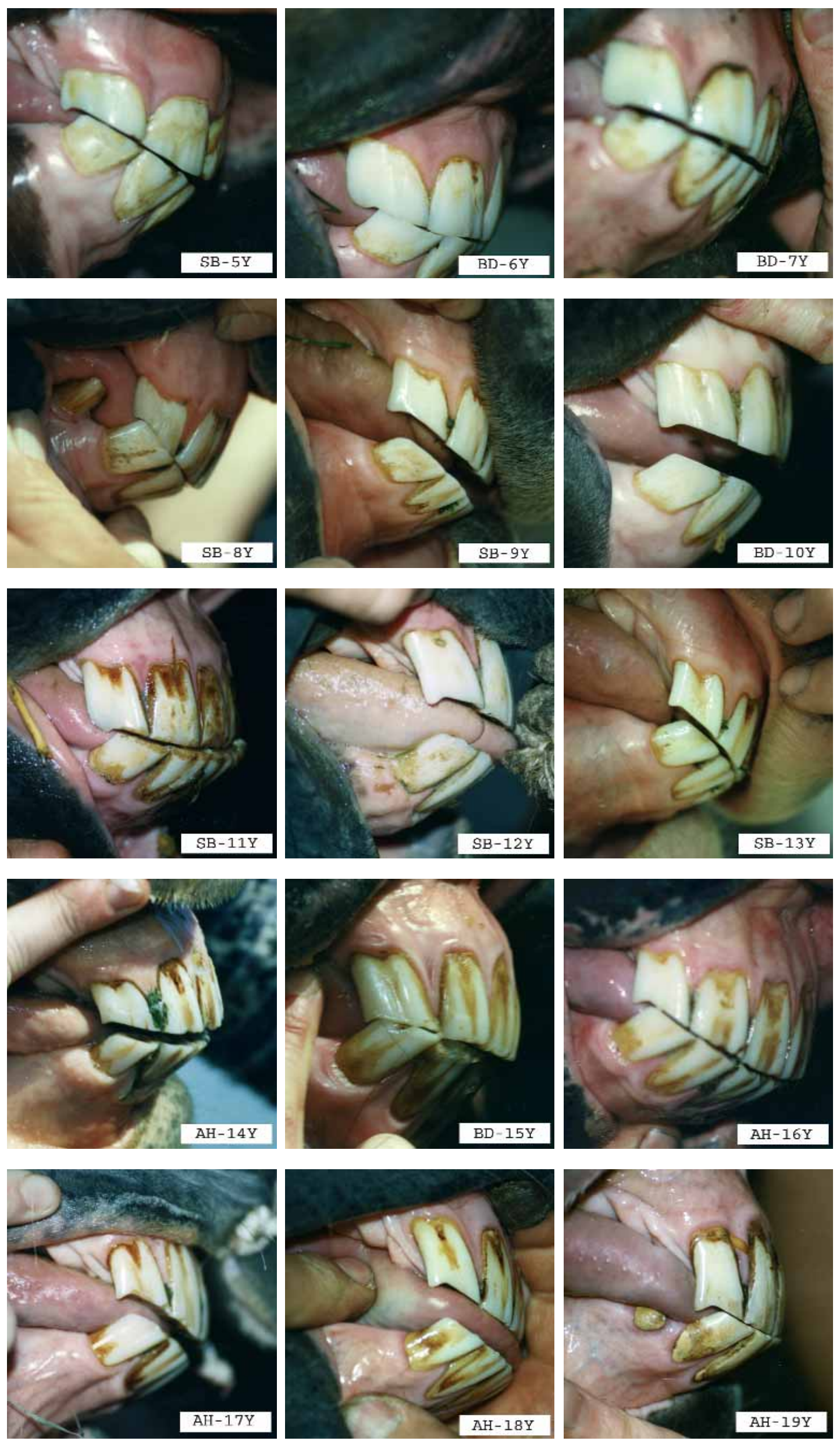


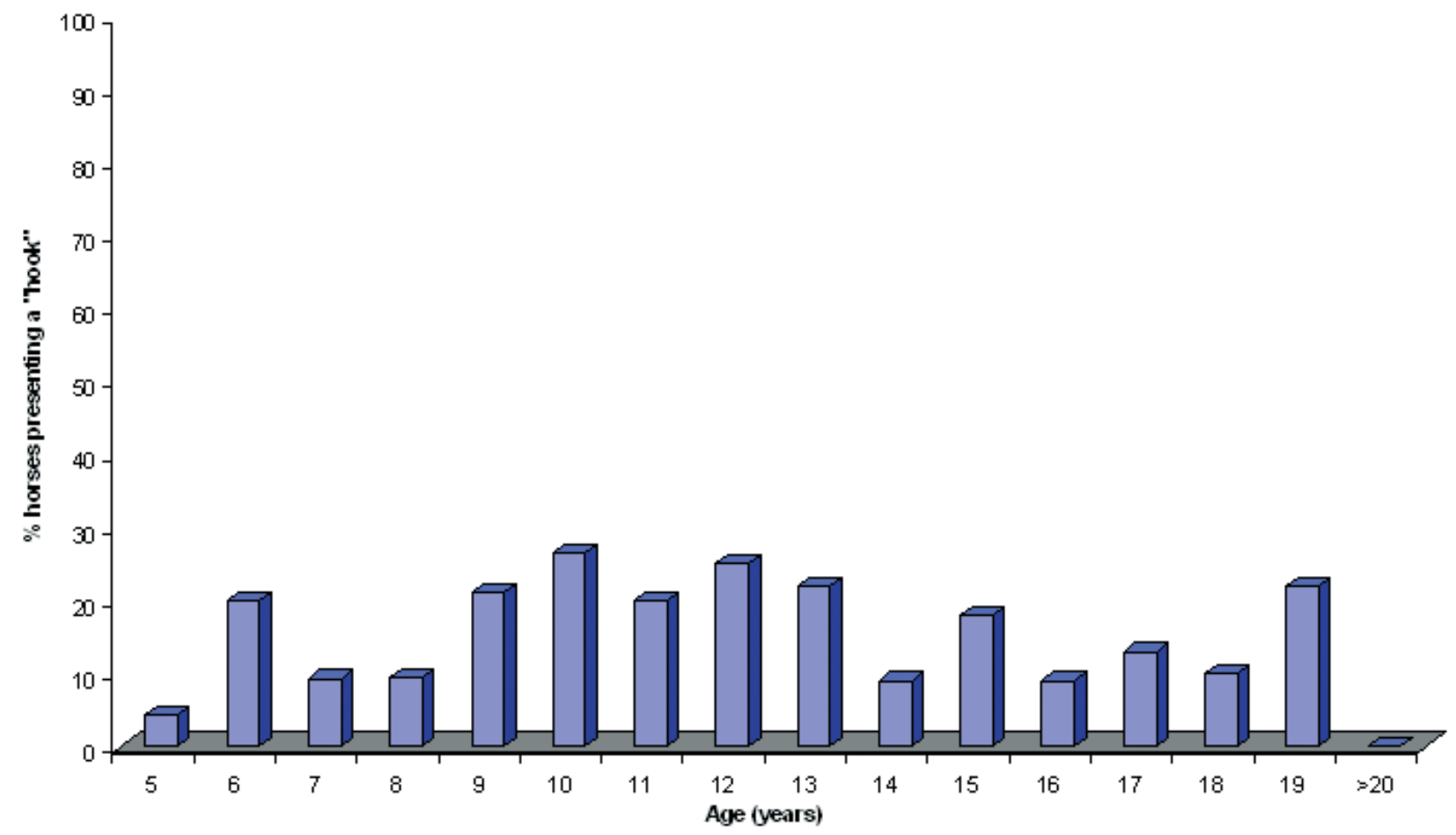

Fig 5 Distribution of horses and ponies $(n=490)$ presenting a hook on one or both upper corners.

Verteilung der Pferde und Ponies $(n=490)$ mit einem Einbiss an einem oder beiden Oberkiefereckschneidezähnen.

vature between upper and lower incisors and on morphologic characteristics of an individual tooth. Another factor influencing the appearance of a hook is the chewing pattern. Unlike man, most mammals have chewing patterns that are consistent both individually and within each species (Easley 1999). There is, however, no standard pattern. The chewing pattern depends on the form of the cheek teeth and the relative abaxial movement of the mandible. Horses appear to be either right-sided or left-sided chewers and this may explain differences of attrition (Easley 1999). The frequently observed unilateral appearance of the hook may be a result of unequal attrition.

The results of the present study illustrate that the presence of both a hook and a Galvayne's groove on the upper corner incisors is very variable in horses. The age-related variation in both features is extremely large and accounts for their nonreliability in dental ageing.

\section{Literature}

American Association of Equine Practitioners (2002): Guide for determining the age of the horse. 6st ed., Fort Dodge, lowa

Baker G. (1985): Oral examination and diagnosis: management of oral diseases. In: Veterinary Dentistry, ed. CE Harvey, WB Saunders, Philadelphia, 217-228.

Baker G. (1999): Equine Dentistry. 1st ed., WB Saunders, London. 3-28

Barone R. (1997): Anatomie des mammifères domestiques; Tome 3: Splanchnologie I. 3rd ed., Vigot, Paris, 133
Dyce K. M., Sack W. O. and Wensing C. J. (1996): Textbook of veterinary anatomy. 2nd ed., WB Saunders, Philadelphia, 491

Easley J. (1999) Equine Dentistry. 1st ed., WB Saunders, London. pp. 29-34

Kertesz P. (1993) In search of Mr Bishop. Vet. Rec. 133, 608-610

McCarthy P. H. (1987): Galvayne: the mystery surrounding the man and the eponym. Anat. Histol. Embryol. 16, 330-336

McMullan W. C. (1983): Dental criteria for estimating age in the horse. Equine Practice 5, 36-43

Muylle S., Simoens P. and Lauwers H. (1996): Ageing horses by examination of their incisor teeth: an (im)possible task? Vet. Rec. 138, 295-301

Muylle S., Simoens P., Lauwers H. and van Loon G. (1997): Ageing draft and trotter horses by their dentition. Vet. Rec. 141, 17-20

Muylle S., Simoens P., Lauwers H. and van Loon G. (1998): Ageing Arab horses by their dentition. Vet. Rec. 142, 650-662

Richardson J. D., Lane J. G. and Waldron K. R. (1994): Is dentition an accurate indication of the age of a horse? Vet. Rec. 135, 31 34

Van Foreest A. (1995): Classificatie, nomenclatuur en identificatie van gebitselementen bij dieren. Tijdschrift voor Diergeneeskunde 120, 234-241

Walmsley J. P. (1993): Some observations on the value of ageing 57 -year-old horses by examination of their incisor teeth. Equine Vet Educ 5, 295-298

Dr. Sofie Muylle

Dept. of Morphology

Faculty of Veterinary Medicine

Ghent University

Salisburylaan 133

9820 Ghent, Belgium

sofie.muylle@ugent.be 